\title{
In Vitro Efficiency of Some Fungicides Against Neoscytalidium dimidiatum (Penz.) Crous and Slippers Causing Sudden Shoot Dry on Apricot Trees
}

\author{
Aysun Eraslan Sür ${ }^{1, a}$, Erçin Oksal ${ }^{2, b, *}$ \\ ${ }^{1}$ Ministry of Agriculture and Forestry, Yazıhan District Directorate of Agriculture and Forestry, 44110 Malatya, Turkey \\ ${ }^{2}$ Department of Plant Protection, Faculty of Agriculture, Malatya Turgut Özal University, 44210 Malatya, Turkey
}

*Corresponding author

A R T I C L E I N F O A B S T R A C T

Research Article

Received : 31/01/2021

Accepted : 06/03/2021

Turkey is known as a top producer and exporter of apricots, both fresh and dried. More than half of Turkey's apricot production is provided by Malatya province. There are many pests and diseases affecting apricots in addition to climatic factors such as frost and hail. Partial shoot drying and sudden drying in apricot orchards have increased in recent years. In this study, it was aimed to determine the chemical control possibilities of Neoscytalidium dimidiatum (Penz.) Crous \&Slippers, which is one of the fungal agents that cause partial branch drying and sudden drying in apricot orchards in Malatya province by in vitro studies. For this purpose, Kale 4-C isolate of $N$. dimidiatum collected from Malatya in a previous study was used. Mycelial growth of $N$. dimidiatum Kale 4-C isolate in PDA were observed in 0 (control), 0.01, 0.03, 0.1, 1, 3, 10, 30 ve $100 \mu \mathrm{g} / \mathrm{mL}$ concentrations of Azoxystrobin $250 \mathrm{~g} / \mathrm{L}$, Trifloxystrobin \%50, Tebuconazole \%25, Floupyram 200 g/L+Tebuconazole $200 \mathrm{~g} / \mathrm{L}$, Cyprodinil+Fludioxonil $\% 37.5+25, \% 70$ Thiophanate-Methyl and 400

Keywords:

Neoscytalidium dimidiatum $200 \mathrm{~g} / \mathrm{L}+$ Tebuconazole $200 \mathrm{~g} / \mathrm{L}$ ve Cyprodinil+Fludioxonil $\% 37.5+25$ fungicides effectively Fungicide

Chemical control

Botryosphaeriaceae

inhibited the mycelial growth of the fungus.

aysuneraslan01@windowslive.com (i) Http://orcid.org/0000-0002-7409-1932|b@oksalercin@gmail.com

http://orcid.org/0000-0002-7049-4419

(c) (1) (8) This work is licensed under Creative Commons Attribution 4.0 International License

\section{Introduction}

Turkey has a location where climate and soil conditions are appropriate for cultivating several crops. Turkey is among important fruit cultivating countries throughout the World. One of the most grown fruit crops is apricot in Turkey (Ercisli, 2009).

Apricot (Prunus armeniaca L.) belongs to Rosales order, Rosaceae family, Prunoidae sub-family, Prunus genus, and Prunophora sub-genus (Janick and Moore, 1979). Centers of origin of apricot is a wide area from East Turkistan to China and the cultivation of it in Anatolia dates from 2000 years ago (Asma, 2000; Eriş ve Barut, 2000; Gülcan, 2001; Özçağıran ve ark. 2004; Sevindik et al., 2020). Apricot is widely cultivated in Elaziğg-ErzincanSivas provinces, Mediterranean Region, Kars-Iğdır provinces, Agean Region, Central Anatolia Region, and Thrace Region in Turkey where it is widely grown in Malatya province with different cultivars and different intensities (Asma, 2000; Asma ve Kan, 2001; Durmuş ve Yiğit, 2003; Ercisli, 2004). Turkey supplies $20 \%$ and 85-
$90 \%$ of fresh and dried apricot production of the world, respectively (Gezer et al, 2003).

Apricot production varies according to the years affected by climatic factors, primarily spring late frosts as well as diseases and pests. The reverse effects of these biotic and abiotic agents cause economically serious crop losses. The main diseases of apricot are Monilinia laxa Aderh et Ruhl and Monilinia fructigena Aderh et Ruhl, Coryneum beijerinckii Oudem), Cytospora cincta Sacc.) Pseudomonas syringae pv syringae Van. Hall, Plum pox virus) and root rot diseases such as Armillaria mellea (Vall) Quel. and Rosellinia necatrix Prill. (Asma, 2000, Kayg1siz, 2000).

Besides these diseases, $N$. dimidiatum was detected as one of the most important agents responsible for the sudden drying of branches and shoots causing economic losses in apricot orchards (Oksal and Özer, 2020). The necessity for this study was that there were limited studies in the World and no research about the chemical control of this disease 
in apricot. It was aimed to determine the chemical control possibilities against $N$. dimidiatum in apricot and to prevent the unnecessary or excessive usage of chemicals within this study

\section{Materials and Methods}

The isolate used in the study is the most pathogenic isolate obtained from a previous study, $N$. dimidiatum Kale 4-C. Potato dextrose agar (PDA) was used to observe the mycelial growth and water agar (WA) was used to investigate conidia germination of $N$. dimidiatum 4-C isolate in efficacy determining studies of the isolate against fungicides. Other fungicides used in the study are shown in Table 1.

\section{Determination of Effects of Fungicides on Mycelial Growth of N. Dimidiatum}

PDA (Merck, Germany) was prepared for each concentration of the fungicides individually, autoclaved at $121^{\circ} \mathrm{C}$ for $20 \mathrm{~min}$, and cool down to $40-45^{\circ} \mathrm{C}$. Fungicides used in the trials were weighed and stock solutions and dilutions were prepared in sterile water.

Fungicides trials were performed with the concentrations of 0 (control) $0.01,0.03,0.1,1,3,10,30$, and $100 \mu \mathrm{g} / \mathrm{mL}$ active substances to determine the inhibition rates of the mycelial growth of the isolate. These concentrations were prepared from the stock solutions from active substance concentration. Prepared PDA growth cultures were sterilized and cooled down to 45 $55^{\circ} \mathrm{C}$ and fungicide concentrations prepared from stock solutions were added. Growth media were poured into 9 $\mathrm{cm}$ diameter sterile Petri dishes $20 \mathrm{~mL}$ for each. These growth media were dried for 1-2 days and later were inoculated with colony disks of fungicide-free isolates with the help of a $4 \mathrm{~mm}$ diameter cork-borer. The side of fungal growth of the disks were inoculated to growth media as 3 disks for each petri dish.

After isolation, the inoculated isolates were incubated in dark conditions for 7 days $25^{\circ} \mathrm{C}$. Trials were performed as 5 repetitions for each isolate and for each concentration. Petri dishes were observed after the 4th day and it was noticed that colonies got close to the petri edge on the 7 th day. So, the diameters of the colonies of control and fungicide concentration were measured in three different directions and arithmetic mean was calculated on the 7 th day. The colony diameter of the control was admitted as $100 \%$ and the growth rate of the fungicide concentration applied colonies were determined by comparing the diameters with the control.

\section{Determination of Effects of Fungicides on Conidia Germination}

Water agar (WA, $1.5 \%$ ) was prepared, sterilized, and cooled down to $40^{\circ} \mathrm{C}$. In the meantime, fungicides were weighed and stock solutions and dilutions were prepared in sterile water. Fungicide concentrations of 0 (control), 0.1, $1,3,10,30$, and $100 \mu \mathrm{g} / \mathrm{mL}$ prepared from the stock solutions were added to the growth media and poured to 9 $\mathrm{cm}$ diameter petri dishes $20 \mathrm{~mL}$ for each and let dry for one day. $N$. dimidiatum Kale 4-C isolate was grown in PDA at $25^{\circ} \mathrm{C}$ for 3-7 days in dark conditions for abundant sporulation to be used in the trials. $5-10 \mathrm{~mL}$ distilled water was added to the petri dishes, conidia were harvested by sterile baget and filtered from a filter paper. The intensity of conidia suspension was adjusted to $1 \times 10^{6}$ conidia $/ \mathrm{mL}$ by Thoma slide. $0.2 \mathrm{~mL}$ of this suspension was added to the growth media containing fungicide and control growth media and to agar surface via sterile bacteria diffuser. Petri dishes with conidia suspensions were incubated at $25^{\circ} \mathrm{C}$ in dark conditions for 24-48 hours. At the end of this period, conidia germination was controlled and conidias were counted when there was $90 \%$ germination in the control petri dishes. 100 conidia for each petri dish were counted under the microscope and conidia numbers and germination rates were calculated (Figure 1). Trials were performed for 5 repetitions for each concentration of the fungicide.

\section{Statistical Analysis}

Data obtained from the study were subjected to variance analyses via package software and the differences between the means were determined by the LSD test $(\mathrm{P} \leq 0.05)$. Percentage effects of fungicides were calculated according to the Abbott formula (Abbott, 1925).

\section{Results and Discussion}

Parameter values obtained from this study were shown in Table $2 \mathrm{a}, \mathrm{b}$. The study was repeated two times with 5 repetitions for each trial and both were evaluated together since there was no statistical difference between them. The statistical differences of the chemicals on the conidia germination and mycelial characteristics of $N$. dimidiatum were determined (Table 2, $\mathrm{P}<0.05$ ).

It was determined that fungal growth of $N$. dimidiatum Kale 4-C isolate was completely inhibited in the Floupyram $200 \mathrm{~g} / \mathrm{L}+$ Tebuconazole $200 \mathrm{~g} / \mathrm{L}$ containing media on the 7 th day beginning from the concentration of $10 \mu \mathrm{g} / \mathrm{mL}$. When $\%$ effects were analysed, the most effective concentrations were found to be 10,30 , and $100 \mu \mathrm{g} / \mathrm{mL}$ with $100 \%$ effect following 3.1 , and $0.1 \mu \mathrm{g} / \mathrm{mL}$ concentrations with the rate of 90.56, 84.70, and 72.7\%, respectively (Figure 2).

Fungal growth of $N$. dimidiatum Kale 4-C isolate was completely inhibited in the Cyprodinil+Fludioxonil $37.5 \%+25$ containing media beginning with the concentration of $30 \mu \mathrm{g} / \mathrm{mL}$ on the 7 th day. When $\%$ effects were analysed, the most effective concentrations were found to be 30 and $100 \mu \mathrm{g} / \mathrm{mL}$ containing media with $100 \%$ inhibition effect. No inhibition effect was determined in 0.01 ve $0.03 \mu \mathrm{g} / \mathrm{mL}$ concentrations (Figure 3 ).

The most effective inhibition in Trifloxystrobin $\% 50$ containing media was found to be $100 \mu \mathrm{g} / \mathrm{mL}$ concentration on the 7 th day whereas the most effective concentrations were found to be 100 and $3 \mu \mathrm{g} / \mathrm{mL}$ concentrations following them with $30,10,1$, ve 0.03 $\mu \mathrm{g} / \mathrm{mL}$ concentrations against $N$. dimidiatum Kale 4-C isolate. No inhibition effect was observed in $0.01 \mu \mathrm{g} / \mathrm{mL}$ concentration.

The most effective inhibition against $N$. dimidiatum Kale 4-C isolate was determined to be $100 \mu \mathrm{g} / \mathrm{mL}$ concentrations in Azoxystrobin $250 \mathrm{~g} / \mathrm{L}$ containing media. The most effective concentrations were found to be 100 and $30 \mu \mathrm{g} / \mathrm{mL}$ concentrations following $10 \mu \mathrm{g} / \mathrm{mL}$ concentration. No inhibition effect was observed in 3,1 , $0.1,0.03$ and $0.01 \mu \mathrm{g} / \mathrm{mL}$ concentrations. 
Table 1. General information about fungicides used in this study

\begin{tabular}{l|lccc}
\hline \multicolumn{1}{c|}{ Active substance and quantity } & Ft & Application dose/100L water & Fungicide group & Commercial name \\
\hline Azoxystrobin $250 \mathrm{~g} / \mathrm{L}$ & $\mathrm{SC}$ & $50 \mathrm{~mL}-75 \mathrm{~mL}-100 \mathrm{~mL}$ & Strobilurin & QUADRIS $^{\circledR}$ \\
Trifloxystrobin $50 \%$ & WG & $10 \mathrm{~g}-12.5 \mathrm{~g}-15 \mathrm{~g}$ & Strobilurin & FEATURE $^{\circledR}$ \\
Tebuconazole $25 \%$ & $\mathrm{WP}$ & $40 \mathrm{~g}-60 \mathrm{~g}-80 \mathrm{~g}$ & Triazole & FOLICUR $^{\circledR}$ \\
Floupyram $200 \mathrm{~g} / \mathrm{L}+$ Tebuconazole $200 \mathrm{~g} / \mathrm{L}$ & $\mathrm{SC}$ & $15 \mathrm{~mL}-25 \mathrm{~mL}-35 \mathrm{~mL}$ & Benzamide + Triazole & LUNA $^{\text {EXERIENCE }}$ \\
Cyprodinil +Fludioxonil $37.5 \%+25$ & $\mathrm{WG}$ & $30 \mathrm{~g}-40 \mathrm{~g}-50 \mathrm{~g}$ & Pyrimidine + Pyrrole & SWITCH $^{\circledR}$ \\
$\% 70$ Thiophanate-Methyl & $\mathrm{WP}$ & $40 \mathrm{~g}-60 \mathrm{~g}-80 \mathrm{~g}$ & Benzimidazole & SUMITOP $^{\circledR}$ \\
\hline $400 \mathrm{~g} / \mathrm{L}$ Phosphorous Acide & $\mathrm{SL}$ & $300 \mathrm{~mL}-400 \mathrm{~mL}-500 \mathrm{~mL}$ & & AGRİ-FOS $^{\circledR}$ \\
\hline Ft: Formulation type & & & &
\end{tabular}

Ft: Formulation type

Table 2a. The effects of chemicals with different concentrations on mycelial growth and conidia germination of Neoscytalidium dimidiatum

\begin{tabular}{|c|c|c|c|c|c|c|}
\hline \multirow[b]{2}{*}{ Actives } & \multicolumn{3}{|c|}{ Effect against mycelial growth } & \multicolumn{3}{|c|}{ Effect against conidia germination } \\
\hline & $\begin{array}{l}\text { Doses } \\
\mu \mathrm{g} / \mathrm{mL}\end{array}$ & $\begin{array}{l}\text { Average mycel } \\
\text { diameter }(\mathrm{mm})\end{array}$ & $\begin{array}{c}\% \\
\text { Effect }\end{array}$ & $\begin{array}{l}\text { Doses } \\
\mu \mathrm{g} / \mathrm{mL}\end{array}$ & $\begin{array}{l}\text { germinate } \\
\text { (number) }\end{array}$ & $\begin{array}{c}\% \\
\text { Effect }\end{array}$ \\
\hline \multirow{10}{*}{ Azoxystrobin $250 \mathrm{~g} / 1$} & 0.01 & $6.25^{\mathrm{a}}$ & & - & - & - \\
\hline & 0.03 & $6.25^{\mathrm{a}}$ & 0.00 & - & - & - \\
\hline & 0.1 & $6.25^{\mathrm{a}}$ & 0.00 & 0.1 & $92.80^{\mathrm{b}}$ & 4.33 \\
\hline & 1 & $6.25^{\mathrm{a}}$ & 0.00 & 1 & $89.60^{c}$ & 7.63 \\
\hline & 3 & $6.25^{\mathrm{a}}$ & 0.00 & 3 & $88.40^{\mathrm{c}}$ & 8.87 \\
\hline & 10 & $1.77^{\mathrm{b}}$ & 0.00 & 10 & $85.20^{\mathrm{d}}$ & 12.16 \\
\hline & 30 & $1.44^{\mathrm{c}}$ & 71.68 & 30 & $81.20^{\mathrm{e}}$ & 16.29 \\
\hline & 100 & $1.18^{\mathrm{d}}$ & 76.90 & 100 & $74.60^{\mathrm{f}}$ & 23.09 \\
\hline & Control & $6.25^{\mathrm{a}}$ & 81.06 & Control & $97.00^{\mathrm{a}}$ & 0.00 \\
\hline & LSD & 0.14 & & LSD & 2.40 & \\
\hline \multirow{10}{*}{ Trifloxystrobin $50 \%$} & 0,01 & $6.25^{\mathrm{a}}$ & 0.00 & - & - & - \\
\hline & 0.03 & $2.20^{\mathrm{b}}$ & 64.80 & - & - & - \\
\hline & 0.1 & $2.22^{\mathrm{b}}$ & 64.48 & 0.1 & $92.20^{\mathrm{b}}$ & 4.95 \\
\hline & 1 & $1.64^{\mathrm{c}}$ & 73.76 & 1 & $88.20^{\mathrm{c}}$ & 9.07 \\
\hline & 3 & $1.10^{\mathrm{e}}$ & 82.40 & 3 & $87.80^{c}$ & 9.48 \\
\hline & 10 & $1.30^{\mathrm{de}}$ & 79.20 & 10 & $83.80^{\mathrm{d}}$ & 13.61 \\
\hline & 30 & $1.14^{\mathrm{d}}$ & 81.76 & 30 & $75.30^{\mathrm{e}}$ & 22.47 \\
\hline & 100 & $0.88^{f}$ & 85.92 & 100 & $24.20^{\mathrm{f}}$ & 75.05 \\
\hline & Control & $6.25^{\mathrm{a}}$ & 0.00 & Control & $97.00^{\mathrm{a}}$ & 0.00 \\
\hline & LSD & 0.17 & & LSD & 1.97 & \\
\hline \multirow{10}{*}{ Tebuconazole $25 \%$} & 0.01 & $6.25^{\mathrm{a}}$ & 0.00 & - & - & - \\
\hline & 0.03 & $6.25^{\mathrm{a}}$ & 0.00 & - & - & - \\
\hline & 0.1 & $6.25^{\mathrm{a}}$ & 0.00 & 0.1 & $93.60^{\mathrm{a}}$ & 3.51 \\
\hline & 1 & $1.62^{\mathrm{a}}$ & 74.05 & 1 & $80.00^{\mathrm{b}}$ & 17.53 \\
\hline & 3 & $1.42^{\mathrm{a}}$ & 77.31 & 3 & $82.00^{\mathrm{b}}$ & 15.46 \\
\hline & 10 & $1.10^{\mathrm{b}}$ & 82.34 & 10 & $91.80^{\mathrm{c}}$ & 5.36 \\
\hline & 30 & $0.63^{b}$ & 89.92 & 30 & $76.40^{\mathrm{d}}$ & 21.24 \\
\hline & 100 & $0.00^{\mathrm{b}}$ & 100.00 & 100 & $79.40^{\mathrm{d}}$ & 18.14 \\
\hline & Control & $6.25^{\mathrm{a}}$ & 0.00 & Control & $97.00^{\mathrm{a}}$ & 0.00 \\
\hline & LSD & 9.93 & & LSD & 3.73 & \\
\hline \multirow{10}{*}{$\begin{array}{l}\text { Floupyram } 200 \\
\text { g/L+Tebuconazole } 200 \mathrm{~g} / \mathrm{L}\end{array}$} & 0.01 & $1.87^{\mathrm{b}}$ & 70.11 & - & - & - \\
\hline & 0.03 & $2.08^{\mathrm{c}}$ & 66.66 & - & - & - \\
\hline & 0.1 & $1.70^{\mathrm{d}}$ & 72.74 & 0.1 & $8.60^{\mathrm{b}}$ & 7.63 \\
\hline & 1 & $0.96^{\mathrm{e}}$ & 84.70 & 1 & $74.60^{c}$ & 23.09 \\
\hline & 3 & $0.59^{\mathrm{e}}$ & 90.56 & 3 & $40.60^{\mathrm{d}}$ & 58.14 \\
\hline & 10 & $0.00^{f}$ & 100.00 & 10 & $56.80^{\mathrm{e}}$ & 41.44 \\
\hline & 30 & $0.00^{f}$ & 100.00 & 30 & $9.60^{f}$ & 90.10 \\
\hline & 100 & $0.00^{f}$ & 100.00 & 100 & $7.00^{f}$ & 92.78 \\
\hline & Control & $6.25^{\mathrm{a}}$ & 0.00 & Control & $97.00^{\mathrm{a}}$ & 0.00 \\
\hline & LSD & 0.10 & & LSD & 5.83 & \\
\hline \multirow{10}{*}{$\begin{array}{l}\text { Cyprodinil +Fludioxonil } \\
37.5 \%+25\end{array}$} & 0.01 & $6.25^{\mathrm{a}}$ & 0.00 & - & - & - \\
\hline & 0.03 & $6.25^{\mathrm{a}}$ & 0.00 & - & - & - \\
\hline & 0.1 & $0.49^{\mathrm{b}}$ & 92.21 & 0.1 & $90.20^{\mathrm{b}}$ & 7.01 \\
\hline & 1 & $0.31^{\mathrm{c}}$ & 95.04 & 1 & $29.80^{c}$ & 69.28 \\
\hline & 3 & $0.24^{\mathrm{c}}$ & 96.10 & 3 & $17.60^{\mathrm{d}}$ & 81.86 \\
\hline & 10 & $0.12^{\mathrm{d}}$ & 98.02 & 10 & $9.20^{\mathrm{e}}$ & 90.52 \\
\hline & 30 & $0.00^{\mathrm{e}}$ & 100.00 & 30 & $8.20^{\mathrm{e}}$ & 91.55 \\
\hline & 100 & $0.00^{\mathrm{e}}$ & 100.00 & 100 & $6.80^{\mathrm{e}}$ & 92.99 \\
\hline & Control & $6.25^{\mathrm{a}}$ & 0.00 & Control & 97.00 & 0.00 \\
\hline & LSD & 0.11 & & LSD & 5.45 & \\
\hline
\end{tabular}


Table $2 \mathrm{~b}$. The effects of chemicals with different concentrations on mycelial growth and conidia germination of Neoscytalidium dimidiatum

\begin{tabular}{l|cccccc}
\hline \multirow{3}{*}{ Actives } & \multicolumn{3}{|c}{ Effect against mycelial growth } & \multicolumn{3}{c}{ Effect against conidia germination } \\
\cline { 2 - 7 } & $\begin{array}{c}\text { Doses } \\
\mu \mathrm{g} / \mathrm{mL}\end{array}$ & $\begin{array}{c}\text { Average mycel } \\
\text { diameter }(\mathrm{mm})\end{array}$ & $\begin{array}{c}\% \\
\text { Effect }\end{array}$ & $\begin{array}{c}\text { Doses } \\
\mu \mathrm{g} / \mathrm{mL}\end{array}$ & $\begin{array}{c}\text { Average germinated } \\
\text { conidia (number) }\end{array}$ & $\begin{array}{c}\% \\
\text { Effect }\end{array}$ \\
\hline & 0.01 & $6.25^{\mathrm{a}}$ & 0.00 & - & - & - \\
& 0.03 & $6.25^{\mathrm{a}}$ & 0.00 & - & - & - \\
& 0.1 & $6.25^{\mathrm{a}}$ & 0.00 & 0.1 & $96.80^{\mathrm{a}}$ & 0.21 \\
& 1 & $1.74^{\mathrm{b}}$ & 72.10 & 1 & $95.20^{\mathrm{a}}$ & 1.86 \\
& 3 & $1.04^{\mathrm{c}}$ & 83.39 & 3 & $92.20^{\mathrm{b}}$ & 4.95 \\
& 10 & $1.38^{\mathrm{d}}$ & 77.98 & 10 & $88.80^{\mathrm{c}}$ & 8.45 \\
& 30 & $1.26^{\mathrm{e}}$ & 79.87 & 30 & $76.00^{\mathrm{d}}$ & 21.65 \\
& 100 & $0.81^{\mathrm{f}}$ & 87.01 & 100 & $25.00^{\mathrm{e}}$ & 74.23 \\
& Control & $6.25^{\mathrm{a}}$ & 0.00 & Control & $97.00^{\mathrm{a}}$ & 0.00 \\
& LSD & 0.08 & & LSD & 2.65 & - \\
\hline \multirow{5}{*}{$400 \mathrm{~g} / \mathrm{l}$ Phosphanate-Methyl } & 0.01 & 6.25 & 0.00 & - & - & - \\
& 0.03 & 6.25 & 0.00 & - & - & - \\
& 0.1 & 6.25 & 0.00 & 0.1 & $97.00^{\mathrm{a}}$ & 0.00 \\
& 1 & 6.25 & 0.00 & 1 & $96.60^{\mathrm{a}}$ & 0.41 \\
& 3 & 6.25 & 0.00 & 3 & $92.40^{\mathrm{b}}$ & 4.74 \\
& 10 & 6.25 & 0.00 & 10 & $95.60^{\mathrm{b}}$ & 1.44 \\
& 30 & 6.25 & 0.00 & 30 & $95.20^{\mathrm{c}}$ & 1.86 \\
& 100 & 6.25 & 0.00 & 100 & $94.20^{\mathrm{d}}$ & 2.89 \\
& Control & 6.25 & 0.00 & Control & $97.00^{\mathrm{a}}$ & 0.00 \\
\hline
\end{tabular}

The most effective inhibition in Thiophanate-Methyl $70 \%$ containing media was found to be in $100 \mu \mathrm{g} / \mathrm{mL}$ concentration against $N$. dimidiatum Kale 4-C isolate on the 7 th day. 100 ve $3 \mu \mathrm{g} / \mathrm{mL}$ concentrations were found to be the most effective concentrations in \% effect followed by $30 \mu \mathrm{g} / \mathrm{mL}$ concentration. No inhibition effect was observed in $0.1,0.03$ and $0.01 \mu \mathrm{g} / \mathrm{mL}$ concentrations.

The most effective inhibition was recorded in 100 $\mu \mathrm{g} / \mathrm{mL}$ concentration in Tebuconazole $25 \%$ containing media against $N$. dimidiatum Kale 4-C isolate on the 7th day. No mycelial growth was observed in this concentration. The most effective inhibition was recorded in 100 and $30 \mu \mathrm{g} / \mathrm{mL}$ concentrations followed by $10 \mu \mathrm{g} / \mathrm{mL}$ concentration. No inhibition effect was observed in 0.1, 0.03 , and $0.01 \mu \mathrm{g} / \mathrm{mL}$ concentrations against the isolate.

No inhibition effect on mycelial growth of the isolate was observed when colony diameters were measured on the 7th day in phosphorus acid-containing media (Figure 4).

Similar results were obtained in conidia germination effects of the fungicides against the pathogen in vitro. Floupyram $200 \quad \mathrm{~g} / \mathrm{L}+$ Tebuconazole $200 \mathrm{~g} / \mathrm{L}$ and Cyprodinil+Fludioxonil $37.5 \%+25$ were found to be effective inhibiting conidia germination of the fungus the least inhibition effect was obtained in phosphorus acidcontaining media.

Lin et al. (2017b) investigated inhibition effects of cyprodinil + fludioxonil, azoxystrobin + difenoconazole, metiram, trifloxystrobin, pyraclostrobin, azoxystrobin, iminoctadine, and tebuconazole fungicides on the mycelial growth and conidia germination of $N$. dimidiatum, the agent of pitaya cancer disease. According to the Petri trial results, cyprodinil + fludioxonil, azoxystrobin + difenoconazole, and tebuconazole chemicals inhibited the mycelial growth of the fungus. The results of this study are parallel with our study results.
XiaoYong et al. (2018), investigated the effects of pyraclostrobin, azoxystrobin, tebuconazole, and hexaconazole against pitaya cancer in China. Fungicides used in Petri trials were found to be effective whereas pyraclostrobin, azoxystrobin and tebuconazole were the most effective chemicals against the fungus in vivo trials. Azoxystrobin and tebuconazole Petri trials show similarity with our study.

K1lınç and Güldür (2020) investigated the effects of five chemicals in vitro conditions against $N$. dimidiatum in pistachio. According to the study results, Azoxystrobin + Propiconazole was found to be the most effective fungicide with $88.49 \%$ effect, whereas Thiophanate methyl + Tetraconazole was the second effective one with $85.51 \%$ effect, the third effective was Pyraclostrobin + Fluaxapyroxad with the effect of $77.77 \%$. The fifth and the sixth effective fungicides were Metrafenone and Phosphorous acid with the effects of $8.73 \%$ and $4.56 \%$, respectively. Within the fungicides used, Phosphorous acid did not Show any inhibitor effect in our study, but only mycelial growth was investigated in the mentioned research.

Inhibition effects of 7 different fungicides against mycelial growth and conidia germination of $N$. dimidiatum, which is an important disease agent in apricot trees were investigated within the study. Especially fungicides with Floupyram 200g/L + Tebuconazole 200 $\mathrm{g} / \mathrm{L}$ and Cyprodinil + Fludioxonil $37.5 \%+25$, which were found to be effective inhibiting mycelial growth of the fungus were hopeful for future studies. But none of the fungicides in the trials inhibited the conidia germination in $100 \%$ percent effect.

$N$. dimidiatum has been detected in apricot, grapevine, willow, walnut, tomato and potato in Turkey until now (Dervis et al., 2019, Turkölmez et al., 2019, Turkölmez et al., 2019, Dervis et al., 2020, Oksal et al., 2020, Oksal et al., 2020). 


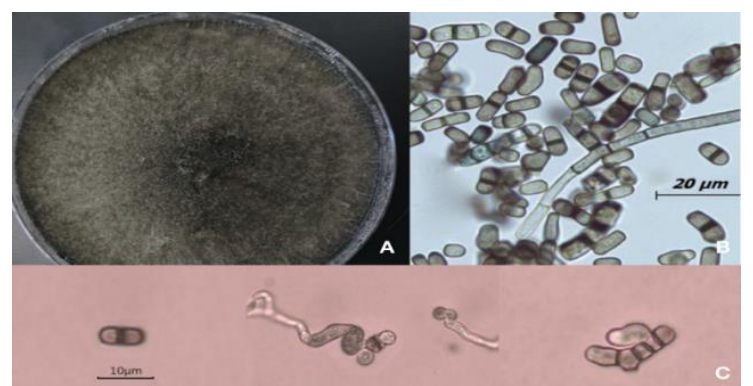

Figure 1. Cultural and morphological characteristics of Neoscytalidium dimidiatum

(A) Coloni on PDA (7 days of incubation at $\left.25^{\circ} \mathrm{C}\right)$; (B) Maturity stages of arthroconidia; (C) Germinated and non-germinated conidia.

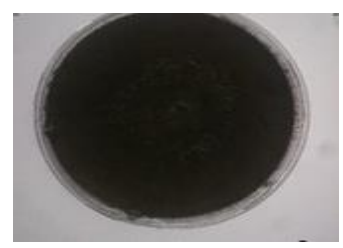

a. Control

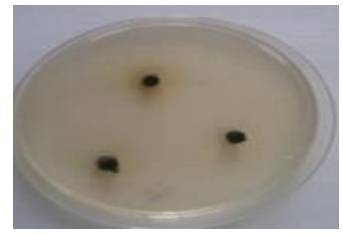

c. $30 \mu \mathrm{g} / \mathrm{mL}$

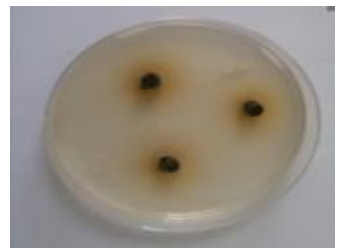

b. $10 \mu \mathrm{g} / \mathrm{mL}$

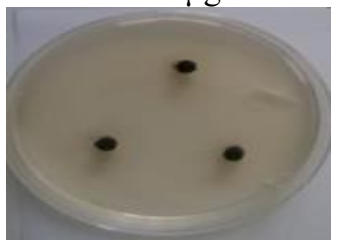

d. $100 \mu \mathrm{g} / \mathrm{mL}$
Figure 2. In vitro efficacy of Floupyram

200g/L+Tebuconazole 200g/L against Neoscytalidium dimidiatum;

(A) Control; (B) $10 \mu \mathrm{g} / \mathrm{mL}$ concentration; (C) $30 \mu \mathrm{g} / \mathrm{mL}$ concentration; (D) $100 \mu \mathrm{g} / \mathrm{mL}$ concentration.

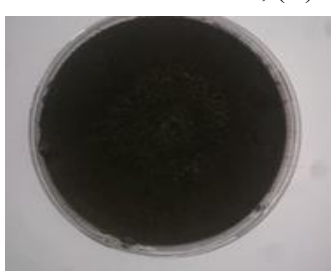

a. Control

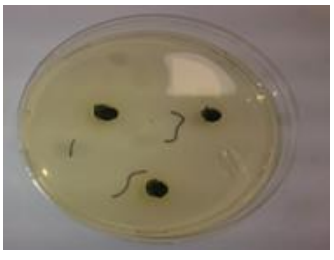

c. $30 \mu \mathrm{g} / \mathrm{mL}$

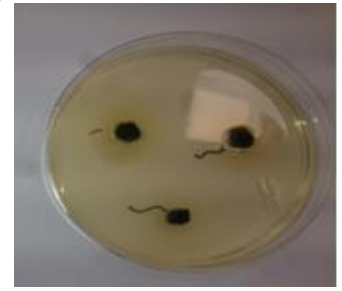

b. $10 \mu \mathrm{g} / \mathrm{mL}$

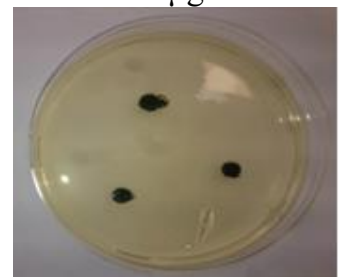

d. $100 \mu \mathrm{g} / \mathrm{mL}$
Figure 3. In vitro efficacy of Cyprodinil+Fludioxonil $\% 37,5+25$ against Neoscytalidium dimidiatum;

(A) Control; (B) $10 \mu \mathrm{g} / \mathrm{mL}$ concentration; (C) $30 \mu \mathrm{g} / \mathrm{mL}$ concentration; (D) $100 \mu \mathrm{g} / \mathrm{mL}$ concentration

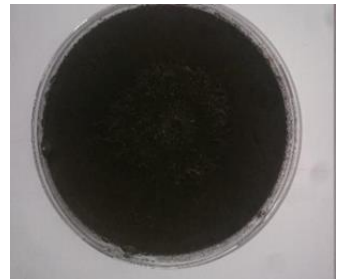

a. Control

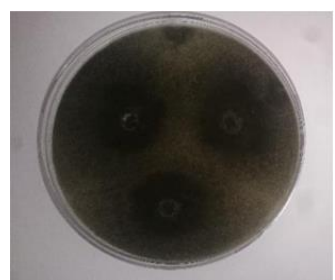

b. $10 \mu \mathrm{g} / \mathrm{mL}$

Figure 4. In vitro efficacy of Phosphorus acid against Neoscytalidium dimidiatum;

(A) Control; (B) $100 \mu \mathrm{g} / \mathrm{mL}$ concentration.
Symptoms of $N$. dimidiatum can be characterized by branch and leaf dryness, bark lesions, discoloration of xylem tissues, longitudinal wood necrosis and extensive gumming. General dieback signs were also observed leading to complete defoliation of leaves and ultimately death of trees in advanced stages. $N$. dimidiatum is becoming a new danger to agricultural production.

Since producers do not carry out cultural practices, hygiene and quarantine precautions are not being applied properly and because of the negative effects of global climate changes on the diseases, fungal diseases cause serious problems lately in apricot.

There are limited studies on biology, epidemiology, and control of the causal agent in different hosts. Field trials are needed to be performed to reveal the accurate effects and to determine the field performances of the fungicides. Field trials will also help to choose the fungicides to be applied in the orchard and nurseries but also fungicide inhibition effects as well as the resistance of the agent against these fungicides should be taken into consideration.

It is thought that study about in vitro trials of fungicides against $N$. dimidiatum will be helpful for future studies since there are limited studies on this subject.

\section{References}

Abbott WS. 1925. A method of computing the effectiveness of an insecticide. Journal of Economic Entomology, 18 (2): 265267.

Asma BM. 2000. Kayısı yetiştiriciliği. Evin Ofset. Malatya, p: 243. Asma BM, Kan T. 2001. Dünya kayısı üretimi ve önemli kayıs1 üreticisi ülkeler. Kayısı Sempozyumu, Malatya, pp: 35-40.

Janick J, Moore JN. 1979. Advances Fruit Breeding. Purdue University Press., West Lafayette, Indiana, USA. pp: $367-$ 383.

Dervis S, Ozer G, Turkölmez Ș. 2020. First report of Neoscytalidium dimidiatum causing tuber rot of potato in Turkey. Journal of Plant Pathology 102: 1295-1296.

Derviş S, Türkölmez Ş, Ulubaş Ç, Çiftçi O, Dikilitaş, M. 2019. First report of Neoscytalidium dimidiatum causing black canker and root rot of walnut in Turkey. Plant Disease. 103 (8): 2129

Durmuş E, Yiğit A. 2003. Türkiye'nin Meyve Üretim Yöreleri. Frrat Üniversitesi Sosyal Bilimler Dergisi, Cilt: 13, Sayı: 2: Sayfa: 23-54

Ercişli S. 2009. Apricot culture in Turkey. Scientific Research and Essay Vol.4 (8): pp: 715-719

Ercişli S. 2004. A short review of the fruit germplasm resources of Turkey. Genetic Resources and Crop Evolution, 51: 419- 435

Eriş A, Barut E. 2000. Ilıman İklim Meyveleri-1. Uludağ Üniversitesi Ders Kitabı. Bursa, No: 6, p: 83

Gezer İ, Acaroğlu M, Hacıseferoğulları H. 2003. Use of Energy and Labour in Apricot Agriculture in Turkey. Biomass and Bioenergy, Volume 24, pp: 215-219.

Gülcan R. 2001. Kayısı Araştırmaları (KAYSAR) Ünitesi Kapsamında Yer Alan Projelerin Tanıtım1, Kayı1 Sempozyumu, Malatya, pp: 14-20.

Kaygısız H. 2000. Bitkisel Üretimde Hastalıklar. Hasat Yayıncilık. İstanbul, p: 221

Kılınç, Güldür. 2020. In Vitro Activities of Some Fungicides Against the Factor of Neoscytalidium dimidiatum Obtained from Pistachio In Şanlıurfa. International Marmara Sciences Congress. 19 - 20 June 2020 Kocaeli, pp: 244

Lin C, Ni H, Huang C, Yang H. 2017. Pathogen Characterization and Chemical Control of Pitaya Stem Canker Disease. Australasian Plant Dissease Notes, 10: 1-4. 
Oksal E, Çelik Y, Özer G. 2019. Neoscytalidium dimidiatum causes canker and dieback on grapevine in Turkey. Australasian Plant Dis. Notes 14, pp: 33

Oksal E, Yiğit T, Özer G. 2020. First report of Neoscytalidium dimidiatum causing shoot blight, dieback and canker of apricot in Turkey. Journal Plant Pathology 102: 579-580.

Özçağıran R, Ünal A, Özeker E, İsfendiyaroğlu M. 2004. Ilıman İklim Meyve Türleri, Vol:1, Ege Üniversitesi Basımevi, Bornova-İzmir, pp: 68.

Sevindik E, Murathan ZT, Sevindik M. 2020. Molecular Genetic Diversity of Prunus armeniaca L. (Rosaceae) Genotypes by RAPD, ISSR-PCR, and Chloroplast DNA (cpDNA) trnL-F Sequences. International Journal of Fruit Science, 20(sup3): S1652-S1661.
Türkölmez Ş, Derviş S, Çiftçi O, Çiğdem US, Türkölmez CG, Dikilitas M. 2019. First Report of Neoscytalidium dimidiatum Causing Dieback, Shoot Blight, and Branch Canker of Willow Trees in Turkey. Plant disease. Vol. 103, No. 8

Türkölmez Ş, Derviş S, Çiftçi O, Çiğdem US, Dikilitas M. 2019. New disease caused by Neoscytalidium dimidiatum devastates tomatoes (Solanum lycopersicum) in Turkey,Crop Protection, Volume 118, pp: 21-30,

XiaoYong X, ShanYu L; GuiNing G, XiaoMei W, Wu Q, GuiDong L, YouChao Z. 2018. Indoor virulence and field effects of fungicides on pitaya canker. Journal of Southern Agriculture 2018 Vol.49 No.7 pp: 1338-1345 